Newman's introduction to the idea of the university. That introduction could be misinterpreted to suggest that the university is not about the advancement of knowledge. Through a careful analysis of many of Newman's essays and lectures Pelikan suggests that the components of a definition of the university should include: "advancement of knowledge through research; extension of knowledge through undergraduate and graduate teaching; training that involves both knowledge and professional skill in the professional programs or schools of the university; preservation of knowledge in libraries, galleries, and museums; and diffusion of knowledge through scholarly publication."

This book is provocative and each of its chapters defines a theme which North American universities should ponder as they recreate or formulate themselves for tomorrow's world. It should be required reading for the first Faculty or Senate meeting of the academic year.

Neave, Guy, and Van Vught, Frans A. (eds.). Prometheus Bound: The Changing Relationship Between Government and Higher Education in Western Europe. Pergamon Press, 1991, 255 pages. Reviewed by Kjell Rubenson, Centre for Policy Studies in Education, University of British Columbia.

This book provides an efficient introduction to the general policy and operational issues affecting the relationship since 1950 of governments in Western Europe with their respective systems of "higher" education, with emphasis on actions and trends over the past decade. Australia and U.S.A. commentaries are included as significant referents.

The introduction by Neave proposes the thesis that relationships of governments to their university systems since World War Two can be characterized by three phases. The first two are proposed as "facilitatory government" (the great quantitative expansion of the 1950s and 1960s), and "interventionist government" (the period of attempts during the 1970s and ' 80 s to control costs and to manage the social, political, and economic impact of the expansion). A third, relatively recent phase, is referred to as "evaluative government" and is accompanied by the rhetoric of supply side economics and the "market." It is the notion of dealing with higher education indirectly, through reduced block financing, conditional research funding, performance and expectation management, and marginal contracting. 
The body of the book consists of free-standing essays (of somewhat even structure and content) by scholars describing their own countries/higher education systems, from the perspective of government relationships and patterns of governance and control. The essays are intended to assess the degree to which the overall thesis seems to hold true for the particular country. The concluding chapter is a synthesis and analysis by both editors, that carries traces of the argumentation between them that (doubtless) led to the compilation itself.

Out of the discussion regarding the degree to which there is a discernible tendency of government to reduce its directly controlling activities, has come a different paradigm - that of government's tendency to substitute "product" control for "process" control. Comments are made that efforts to define educational or training products continue to be fraught with difficulty - to the satisfaction of many of the actors involved.

Both the original and the evolved propositions would appear to be useful constructs in reviewing and making sense out of the untidy processes and behaviours of institutions - governments, ministries of government, and universities all.

The case for either of these formulations as a basis for predicting behaviour or events is not made. The final chapter points out that, even in circumstances of official distancing of government from universities, in fact, arrangements are made to ensure a direct relationship of government to that which is viewed as politically sensitive. On the other hand, it seems clear that most governments have found that there is educational territory within which they meddle at their political peril, because government at that point becomes accountable, rather than the institution. This truth is self-evident in most educational institutions, in a different form - that of the relationship of administrations and Boards of Governors to their faculty/teachers.

The official withdrawal of governments from certain kinds of control and involvement with universities would seem to be tactical only - and not the dawn of a new era of organizational freedom or license.

The differences between the Napoleonic, British, and German systems of higher education and the machinations involved in federal, as opposed to relatively unitary systems, are inherently interesting - especially, perhaps, to Canadians. It is clear that we are not alone. The Belgian report is exquisitely germane to our on-going difficulties in harmonizing different solidly institutionalized traditions and expectations in an environment of rapid social and economic change. 
The title of the book is a trifle misleading. Most essays and the commentary of the editors make reference to "higher education" as including non-university components (differing by country, depending on the specific structure). In most cases, polytechnic and advanced technical institutions are given formal inclusion. In some cases, vocational and "adult" education are also included, as in the American report and in Australia's "tertiary" formulation. The vast bulk of discourse, however, including the sense of meaning and dynamics of relationship, relate to, or presume a university context. This is unfortunate, as universities are only a part - a very important part - of the story. Those essays taking this into account by making some reference to cross-political and fiscal impacts, contribute significantly to the discourse. These include the Irish, Swedish, British, and Norwegian reports.

The topic requires additional perspectives. The authors are drawn solely from university or national institute contexts. In an exercise in deriving meaning from public events and activities, a wider range of authorship would have been of benefit, without denying the significance of the insights of the existing authors.

The style of presentation is pleasant, jargon-free, and at times witty. This is especially true of the introduction and conclusion, although the editors give perhaps too much credit to the reader in the classical allusions.

This book is recommended for both general interest and scholarly reading. It is a useful and coherent probe into an increasingly significant field - the very meaning of the education enterprise in a period of changing relationships.

\section{Book Notes}

\section{Higher Education Books}

Dyanne Gibson. The Student's Guide to Ontario Universities. Toronto: University of Toronto Press, 1992.

This practical guide provides students with information that will help them make decisions about postsecondary education. It provides a detailed overview of each Ontario university, including Ryerson Polytechnical Institute and the Royal Military College. The guide lists questions to ask universities. It covers such details as academic programs, residences, athletic programs, student services, and admissions policies. 